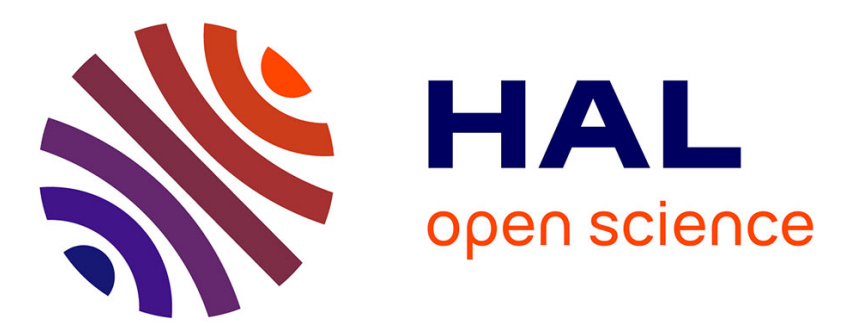

\title{
First evaluation of the effect of microorganisms on steady state hydroxyl radical concentrations in atmospheric waters
}

\author{
A. Lallement, V. Vinatier, M. Brigante, Laurent Deguillaume, A.M. Delort, \\ G. Mailhot
}

\section{To cite this version:}

A. Lallement, V. Vinatier, M. Brigante, Laurent Deguillaume, A.M. Delort, et al.. First evaluation of the effect of microorganisms on steady state hydroxyl radical concentrations in atmospheric waters. Chemosphere, 2018, 212, pp.715 - 722. 10.1016/j.chemosphere.2018.08.128 . hal-01874247

\section{HAL Id: hal-01874247 \\ https://hal.science/hal-01874247}

Submitted on 9 Dec 2020

HAL is a multi-disciplinary open access archive for the deposit and dissemination of scientific research documents, whether they are published or not. The documents may come from teaching and research institutions in France or abroad, or from public or private research centers.
L'archive ouverte pluridisciplinaire $\mathbf{H A L}$, est destinée au dépôt et à la diffusion de documents scientifiques de niveau recherche, publiés ou non, émanant des établissements d'enseignement et de recherche français ou étrangers, des laboratoires publics ou privés. 
A. Lallement ${ }^{1}$, V. Vinatier $^{1}$, M. Brigante ${ }^{1}$, L. Deguillaume ${ }^{2}$, A. M. Delort ${ }^{1 *}$ and G. 5 Mailhot $^{{ }^{*}}$

$6{ }^{1}$ Université Clermont Auvergne, CNRS, SIGMA Clermont, Institut de Chimie de Clermont7 Ferrand, 63000 Clermont-Ferrand, France

${ }^{2}$ Université Clermont Auvergne, CNRS, Laboratoire de Météorologie Physique, 63000

Clermont-Ferrand, France

*Corresponding author: A-marie.Delort@uca.fr, gilles.mailhot@uca.fr

\section{Abstract}

Clouds are complex multiphasic media where efficient chemical reactions take place and where microorganisms have been found to be metabolically active. Hydroxyl radical is the main oxidant in cloud water, and more generally in the atmosphere, during the day and drives the cloud oxidative capacity. However, only one measurement of the steady state hydroxyl radical concentrations in cloud water has been reported so far. Cloud chemistry models are used to estimate the hydroxyl radical concentrations with values ranging from $10^{-12}$ to $10^{-15} \mathrm{M}$ that are surely overestimated due to a lack of knowledge about the speciation of the organic matter acting as a sink for hydroxyl radicals. The aim of this work is to quantify the concentration of hydroxyl radicals at steady state in rain and cloud waters and to measure the impact of native microflora on this concentration. First, the non-toxicity of terephthalic acid as probe is controlled before the analysis in real atmospheric water samples. Higher 
concentrations of hydroxyl radicals are found in cloud waters than in rain waters, with a mean value "1.6 $\pm 1.5 " \times 10^{-16} \mathrm{M}$ and "7.2 $\pm 5.0^{\prime \prime} \times 10^{-16} \mathrm{M}$ for rain and cloud waters respectively and no real impact of microorganisms was observed. This method allows the measurement of steady state hydroxyl radical levels at very low concentrations (down to $10^{-17} \mathrm{M}$ ) and it is biocompatible, fast and easy to handle. It is a useful tool, complementary to other methods, to give a better overview of atmospheric water oxidant capacity.

\section{Keywords}

Cloud water, photochemistry, radical chemistry, oxidative capacity, microorganisms interaction.

\section{Introduction}

Clouds are multiphasic systems where many chemical reactions occur, particularly in droplets (Faust, 1994; Herrmann et al., 2015; Lelieveld and Crutzen, 1991). Very efficient photochemical processes take place inside droplets and chemical reactions within clouds can be faster than the equivalent reactions in the gas phase. The aqueous phase chemistry leads to oxidation processes that can be driven by reactions with radicals. Among the radicals, hydroxyl radical is the most efficient oxidant in the atmosphere (Lelieveld et al., 2004). Several works were carried out on hydroxyl radical chemistry in cloud to define ${ }^{\bullet} \mathrm{OH}$ sources and reactivity (Blough and Zepp, 1995; Chameides and Davis, 1982; Jacob, 1986; Mauldin III et al., 1997). Main sources of hydroxyl radical are i) hydrogen peroxide, nitrite and nitrate photolysis (Yu and Barker, 2003; Zafiriou and Bonneau, 1987; Zellner et al., 1990; Zepp et al., 1987), ii) iron via ligand-to-metal charge-transfer reactions or photo-Fenton chemistry (Deguillaume et al., 2004, 2005; Faust and Hoigné, 1990; Faust and Zepp, 1993; Nakatani et al., 2007; Weschler et al., 1986), iii) the reaction of ozone towards the superoxide radicals and 
iv) the mass transfer of ${ }^{\bullet} \mathrm{OH}$ from the gas phase to the aqueous phase (Arakaki and Faust, 1998; Faust and Allen, 1993). In terms of ${ }^{\bullet} \mathrm{OH}$ sinks, the main way is the reactivity with dissolved organic matter (Arakaki et al., 2013). However, due to the complexity of this environmental matrix, the organic composition is poorly characterized (Herckes et al., 2013); for example, only $21 \%$ of the organic matter in cloud waters sampled at the puy de Dôme station is characterized (Bianco et al., 2016). Furthermore, microorganisms are also present and metabolically active in cloud water. They can survive in spite of numerous stress factors like osmotic shocks, temperature changes and freeze-thaw cycles (Amato et al., 2007a; Joly et al., 2015). In order to survive, they use organic matter as a source of carbon such as short chain aldehydes and carboxylic acids (Amato et al., 2007b; Ariya et al., 2002; Vaïtilingom et al., 2011) but they also have an effect on the oxygenated compounds. As aerobic cells, they are able to consume or either neutralize Reactive Oxygen Species (ROS) like hydroxyl radical, singlet oxygen and hydrogen peroxide. Cloud microorganisms, present in cloud water, have the capacity to degrade hydrogen peroxide and can contribute to the degradation of organic compounds during the day and even more during the night (Vaïtilingom et al., 2010, 2013).

Up to now, the hydroxyl radical concentrations have been estimated using cloud chemistry models. These models consider multiphase chemistry and the mass transfer from the gas to the aqueous phase. Simulated concentrations range from $10^{-12}$ to $10^{-15} \mathrm{M}$ (Deguillaume et al., 2004, 2005, Herrmann et al., 2000, 2010; Mouchel-Vallon et al., 2017; Tilgner and Herrmann, 2010; Tilgner et al., 2013) depending on the chemical scenarios and on the complexity of the chemical mechanisms. For example, the amounts of organic matter and iron are key parameters that drive the level of ${ }^{\bullet} \mathrm{OH}$. Moreover, formation rates of hydroxyl radical in irradiated rain or cloud waters are measured in the laboratory (Faust and Allen, 1993; Nakatani et al., 2007) and are used to evaluate cloud chemistry models (Bianco et al., 2015); 
they express the maximum of ${ }^{\bullet} \mathrm{OH}$ concentration formed without taking into account the different scavengers present in cloud water. The steady state hydroxyl radical concentrations have been estimated in different surface waters (Arakaki et al., 1999; Brezonik and FulkersonBrekken, 1998; Haag and Hoigné, 1985; al Housari et al., 2010; Mill et al., 1980; Qian et al., 2001; Russi et al., 1982; Zepp et al., 1987; Zhou and Mopper, 1990) but, to our knowledge, the study of Anastasio and McGregor (2001) is the only one on cloud water. In their experiments, they used benzene and benzoic acid as chemical probes at concentrations ranging from 50 to $1500 \mu \mathrm{M}$ and analyzed reaction products by HPLC. Because the most concentrated species in cloud water are in the $\mu \mathrm{M}$ range, addition of a probe in high concentration can impact the biological activity which is controlled by the environment (Metallo and Vander Heiden, 2013; Shingler, 2003; Tropel and Meer, 2004). Toxicity issues could also arise. Existing methods must then be adapted to study the impact of microorganisms. Moreover to take biological variability into account several experiments must be performed in parallel with strictly identical conditions.

The main goal of our study is to evaluate the stationary concentration of $\mathrm{OH}$ radicals in atmospheric waters and the potential impact of microorganisms on this concentration. For that purpose we had to develop a specific method which main characteristics are i) to take into account the native microorganisms, and their viability, ii) the use of small volume of sample (300 $\mu \mathrm{L} /$ well) for one measurement so $6 \mathrm{~mL}$ for a complete analysis, and iii) the direct and fast measurement by fluorescence, without chromatography technics.

\section{Experimental section}

\subsection{Chemicals}


Terephthalic acid (TA) (Sigma Aldrich) and 2-hydroxyterephthalic acid (TAOH) (Atlantic Research Chemical), with a purity of 98 and $97 \%$ respectively, are used without additional purification. Acetic acid and $\mathrm{H}_{2} \mathrm{SO}_{4}$ are from Acros Organic. Formic acid, oxalic acid, succinic acid, $\mathrm{K}_{2} \mathrm{SO}_{4}, \mathrm{MgCl}_{2}-6 \mathrm{H}_{2} \mathrm{O}, \mathrm{NO}_{3} \mathrm{NH}_{4}, \mathrm{NaH}_{2} \mathrm{PO}_{4}-2 \mathrm{H}_{2} \mathrm{O}, \mathrm{Na}_{2} \mathrm{HPO}_{4}-2 \mathrm{H}_{2} \mathrm{O}$, ferrozine and hydrogen peroxide (30\% in water, not stabilized) are from Fluka. $\mathrm{CaCl}_{2}-2 \mathrm{H}_{2} \mathrm{O}, \mathrm{NaCl}$, horse radish peroxydase, Tris-EDTA buffer solution, dimethylsulfoxide (DMSO), $\mathrm{FeCl}_{3}-6 \mathrm{H}_{2} \mathrm{O}$ and ethylenediamine-N,N'-disuccinic acid (EDDS) are from Sigma Aldrich. $\mathrm{NaOH}$ is from Merck and 4-hydroxyphenylacetic acid is from Alfa Aesar®.

\subsection{Irradiation setup}

Lamps used for the irradiation setup are tropical terrarium bulb call Reptile UVB (13 W) from Exo Terra®. The polychromatic emission spectrum of the irradiation system reaching the solution is recorded using an optical fiber with a charge coupled device (CCD) spectrophotometer (Ocean Optics USD 2000 + UV-vis) which is calibrated using a DH-2000CAL Deuterium Tungsten Halogen reference lamp. The total irradiance in the UV region of solar spectrum ( 290 and $400 \mathrm{~nm}$ ) reaching the solution is then estimated to be $915 \mu \mathrm{W} \mathrm{cm}-2$.

In Fig. 1, the lamp emission is compared with the solar spectrum measured at the puy de Dôme station under cloudy or clear sky conditions.

\subsection{Sampling and analysis of natural atmospheric waters (cloud and rain)}

Rain samples were collected in September $17^{\text {th }}$, October $28^{\text {th }}$ and December $2^{\text {nd }}, 2015$ and on February $17^{\text {th }}$ and September $15^{\text {th }}, 2016$ on OPGC (Observatoire de Physique du Globe de

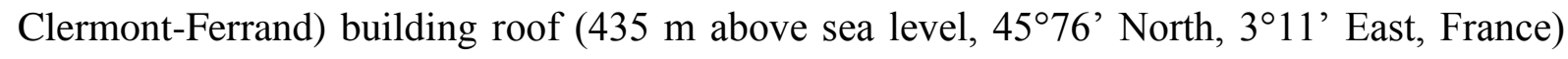
with a homemade pluviometer, composed of sterilized Erlenmeyer flask (2 $000 \mathrm{~mL})$ and sterilized funnel. Cloud waters were collected on February $16^{\text {th }}$, April $1^{\text {st }}$, June $1^{\text {st }}$ and $5^{\text {th }}$ and 
July $2^{\text {nd }}, 2016$ at the puy de Dôme station (1 $465 \mathrm{~m}$ above the sea level, $45^{\circ} 46^{\prime}$ North, $2^{\circ} 57^{\prime}$ East, France) that belongs to the atmospheric survey networks EMEP (the European Monitoring and Evaluation Program), GAW (Global Atmosphere Watch) and ACTRIS (Aerosols, Clouds, and Trace gases Research Infrastructure). For this, a sterilized single-stage cloud collector was used as described in Deguillaume et al. (2014).

Cloud and rain samples are kept in the dark and stored at $4{ }^{\circ} \mathrm{C}$ before the experimentation. Chemical composition analyses are performed on cloud and rain samples through $\mathrm{pH}$, total organic carbon (TOC) concentration, iron concentration and ionic species concentrations. The $\mathrm{pH}$ is measured before and after experimentation with a pH meter MP 225 (Mettler Toledo). TOC analyses are performed with TOC 5050A analyzer (Shimatzu). Concentrations of Fe(II) and $\mathrm{Fe}(\mathrm{III})$ are quantified by spectrophotometric assays after complexation with ferrozine (colorimetric complexing agent) as described by Parazols et al. (2007). Ionic species are quantified by ion chromatography with a Dionex DX320 column for anions and a Dionex ICS1500 column for cations. For microbiological characterization, cells are counted by flow cytometry. Cultured microorganisms are grown on R2A medium at 5 and $17^{\circ} \mathrm{C}$. ATP is measured with BioThema ${ }^{\circledR}$ ATP Biomass kit HS.

Measurements of hydroxyl radical concentrations in atmospheric waters are performed under irradiation and with filtered or non-filtered samples. Waters are filtered just before filling the plate, thanks to a Minisart® PES filter (pore size of $0.22 \mu \mathrm{m}$ and filter diameter of $28 \mathrm{~mm}$ from Sartorius, Germany) under sterilized conditions.

All the vessels are washed with hydrochloric acid solution (2 M) and rinsed with ultrapure water and then sterilized.

\subsection{Determination of steady state hydroxyl radical concentrations}

The detection of ${ }^{\bullet} \mathrm{OH}$ radical is based on the reaction with TA (Fig. 2): 
Among the products formed 2-Hydroxyterephthalic acid (TAOH) is detected and quantified due to its strong fluorescence. However, TAOH is not the unique byproduct and could be instable under irradiation (Page et al., 2010). For these reasons, TAOH formation yield $\left(\gamma_{T A O H}\right)$ was previously described and evaluated as a function of irradiation conditions, temperature and $\mathrm{pH}$ by Charbouillot et al. (2011). In the same work the second order rate constant between TA and ${ }^{\bullet} \mathrm{OH}$ was determined, $k_{T A}=" 4.1 \pm 0.1 " \times 10^{9} \mathrm{M}^{-1} \mathrm{~s}^{-1}$.

In order to obtain the real steady state concentration of ${ }^{\bullet} \mathrm{OH}\left(\left[{ }^{\bullet} \mathrm{OH}\right]_{s s}\right)$, with natural organic matter present in cloud sample, we used the formation rate of $\mathrm{TAOH}\left(R f_{T A O H}\right)$ to calculate the steady state hydroxyl radical concentrations as follows:

$\frac{\frac{d[\mathrm{TAOH}]}{d t}}{\gamma_{T A O H}}=k_{T A} \cdot[\mathrm{TA}] \cdot[\cdot \mathrm{OH}]_{S S}$

So the steady state hydroxyl radical concentration can be calculated as follows:

$[\cdot O H]_{S S}=\frac{\frac{d[T A O H]}{d t}}{\gamma_{T A O H} \cdot k_{T A} \cdot[T A]}$

To determine the steady state concentration, the linear part of the curve between $R f_{T A O H}$ and [TA] is used (Fig. S3). In fact, these conditions represent a low concentration of the probe in order to take into account the impact of all the natural scavengers present in cloud aqueous phase. The slope of the linear part of the equation is then divided by the second-order rate constant between TA and ${ }^{\bullet} \mathrm{OH}\left(k_{T A}\right)$ and by the TAOH formation yield $\left(\gamma_{T A O H}\right)$ as described in equation 2. These experimental conditions enable the determination of the real steady state concentration by taking into account the impact of all the chemical compounds present in the environment. Moreover, the use of TA as probe and the formation of TAOH which is detected by fluorescence spectroscopy, allows for reaching concentrations of ${ }^{\bullet} \mathrm{OH}$ in the order of tenth of femtomolar. 
171 For blank determination 8 measures have been performed in the dark. Limit of detection was

172 calculated as mean blank $+3 \mathrm{SD}_{\text {blank }}$ whereas LOQ was determined as mean blank $+10 \mathrm{SD}$ blank.

173 All the experimental and calculation details are presented in the supplementary data file

174 (Diagram S1, Fig. S1, S2, S3). Note that DMSO is used in order to stop the generation of 175 TAOH during the experiments through light irradiation and/or different chemical processes 176 occurring, thanks to its high reactivity with ${ }^{\bullet} \mathrm{OH}\left(\mathrm{k}_{\mathrm{DMSO}}=6.610^{9} \mathrm{M}^{-1} \mathrm{~s}^{-1}\right)$ (Buxton et al., 177 1988). The addition of $5 \mu \mathrm{L}$ of $\mathrm{DMSO}(1 \mathrm{mM})$ immediately after the sampling does not 178 change significantly the quantification of ${ }^{\bullet} \mathrm{OH}$ (Fig. S4).

179 Finally we tested this protocol to measure $\mathrm{OH}$ radical concentrations at the steady state in controlled conditions using a microcosm mimicking cloud water conditions (artificial marine cloud medium, artificial light, $\mathrm{H}_{2} \mathrm{O}_{2}$ and Fe-EDDS (ethylenediamine-N,N'-disuccinic acid) complex as a source of radicals). The results are reported in the Supplementary Data (Figures S5 and S6).

Wilcoxon test for paired data statistical analysis are performed on hydroxyl radical concentration values to see significant difference ( $\mathrm{R}$ software 3.5.0 used with $\alpha=5 \%$ ).

\subsection{Measurement of hydrogen peroxide concentration}

$\mathrm{H}_{2} \mathrm{O}_{2}$ concentrations are measured using an accurate enzymatic fluorimetric assay with a 4hydroxy-phenylacetic acid that produces a fluorescent dimeric compound with hydrogen peroxide. This method is described in detail in the paper of Vaïtilingom et al. (2013).

\subsection{Assessment of the probe non-toxicity}

193 The non-toxicity of TA to microorganisms was evaluated on Pseudomonas graminis 13b-3, 194 DQ512786 isolated from cloud water sampled at the puy de Dôme station. Pseudomonas graminis $13 \mathrm{~b}-3$ is incubated in $\mathrm{R} 2 \mathrm{~A}$ medium at $17^{\circ} \mathrm{C}$ and $130 \mathrm{rpm}$. After one day of 
incubation, $6 \mathrm{~mL}$ of the culture are centrifuged for $3 \mathrm{~min}$ at $12500 \mathrm{rpm}$. Cells pellets are washed with $\mathrm{NaCl} 0.8 \%$ and cloud artificial medium. Optical density (OD) is taken with a spectrophotometer (at $\lambda=575 \mathrm{~nm}$ ) to obtain cell concentrations that are equal to $10^{6}$ cells $\mathrm{mL}^{-}$ ${ }^{1}$ corresponding to concentration 10 times higher than in natural cloud water. Incubations are done in cloud artificial marine media mimic the typical cloud chemical composition deriving from marine influence. The used concentrations are also ten times higher than those reported in natural cloud water, in order to keep the same ratio between cell and organic compound concentrations. In fact, it has been showed that, at constant ratio "cell concentration/degraded chemical compound concentration" and in the range of concentrations investigated, biodegradation rates are independent of the absolute cell and chemical concentrations (Vaittilingom et al., 2011): acetic acid $2.0 \times 10^{-4} \mathrm{M}$, formic acid $1.45 \times 10^{-4} \mathrm{M}$, oxalic acid $3.0 \times 10^{-5} \mathrm{M}$, succinic acid $1.5 \times 10^{-5} \mathrm{M}, \mathrm{MgCl}_{2}-6 \mathrm{H}_{2} \mathrm{O} 1.0 \times 10^{-4} \mathrm{M}, \mathrm{CaCl}_{2}-2 \mathrm{H}_{2} \mathrm{O} 4.0 \times 10^{-}$ ${ }^{4} \mathrm{M}, \mathrm{K}_{2} \mathrm{SO}_{4} 5.0 \times 10^{-5} \mathrm{M}, \mathrm{NaCl} 2.0 \times 10^{-3} \mathrm{M}, \mathrm{NO}_{3} \mathrm{NH}_{4} 8.0 \times 10^{-4} \mathrm{M}, \mathrm{NaOH} 1.1 \times 10^{-3} \mathrm{M}$ and $\mathrm{H}_{2} \mathrm{SO}_{4} 3.15 \times 10^{-4} \mathrm{M}$. $\mathrm{pH}$ solution is adjusted to 6.1 close to the average $\mathrm{pH}$ of natural clouds representative of air mass from marine origin (Deguillaume et al., 2014). The solution is sterilized with $0.22 \mu \mathrm{m}$ PES filter (Polyethersulfone, diameter $28 \mathrm{~mm}$, membrane of type 16532-k, Sartorius Stedium biotech, Germany) and kept in the dark at $17^{\circ} \mathrm{C}$.

After incubation of cells, the media is tested with different concentrations of TA. At 0,47 and 72 min of incubation, culture is done in $\mathrm{R} 2 \mathrm{~A}$ plate incubated at $17^{\circ} \mathrm{C}$ and ATP concentration is measured with an ATP Biomass kit HS, BioThema ${ }^{\circledR}$.

\section{Results}

\subsection{Validation of the non-toxicity of terephthalic acid}


In order to see the impact of microorganisms on hydroxyl radical concentration, it is crucial to check the non-toxicity of our probe. Pseudomonas graminis 13b-3 isolated in cloud water at the puy de Dôme station is chosen as a model strain because it is representative of the major actors of the cloud microbiota and on which we had already a lot of information available. First it belongs to the Pseudomonas genus which is widely present in puy-de-Dôme cloud samples. From cultural experiments we found this genus in $60 \%$ of our samples (Vaïtilingom et al., 2012) and metatranscriptomics data showed that Pseudomonas strains are among the most active in cloud waters (Amato et al., 2017). In addition we choose the strain Pseudomonas graminis 13-b3 as a model strain because we already studied its metabolism in Vaïtilingom et al (2010, 2011), Husarova et al (2011) and Wirgot et al (2017).

This strain is incubated at a concentration of "1.5 $\pm 0.3 " \times 10^{6}$ cells.mL ${ }^{-1}$ with 3 different probe concentrations $(0,4$ and $10 \mu \mathrm{M})$ in "artificial marine" cloud medium. The evolutions of cell counts and of ATP concentrations as a function of time are presented in Fig. 3.

Whatever the TA concentration, the number of bacteria remains within the same order of magnitude and so no impact of probe concentration is detectable. Similarly, no major change in ATP concentrations is observed with time under all the tested conditions, ranging from 1.6 to $2.6 \times 10^{-6}$ pmol.cell $^{-1}$ with a mean value of $2.0 \times 10^{-6}$ pmol.cell $^{-1}$.

Wirgot et al (2017) showed that Pseudomonas graminis 13-b3 metabolism and particularly its ATP content are very sensitive to environmental conditions. For instance the ATP concentration was highly impacted by the presence of $\mathrm{H}_{2} \mathrm{O}_{2}$, therefore Pseudomonas graminis 13-b3 is a good model to evaluate the impact of our probe on ATP concentration. In the same paper we showed that the results issued from the study of this model strain (a strong correlation between $\mathrm{H}_{2} \mathrm{O}_{2}$ and ATP concentrations) was valid when 32 cloud samples were considered, containing a very diverse biodiversity. In this sense $P$. graminis 13-b3 was a pertinent model for all the cloud microbiota. 
Therefore we can conclude from the results of the present study that terephthalic acid does not impact Pseudomonas graminis 13-b3 viability and energy. In addition we expect that all the microorganisms in cloud water behave in a similar way than our model strain concerning TA toxicity.

Consequently, this probe can be used for measuring microorganism's impact on hydroxyl radical concentration.

\subsection{Hydroxyl radical steady state concentration in atmospheric waters}

With this method, $\left[{ }^{\bullet} \mathrm{OH}\right]_{\mathrm{ss}}$ was evaluated under irradiation $(2$ hours $)$ in various natural atmospheric waters, 5 rain waters and 5 cloud waters sampled in 2015 and 2016. Characterization of these atmospheric waters (including meteorological, physicochemical and biological parameters) and their retro-trajectories over $120 \mathrm{~h}$ are presented in supplementary data (Tables S1 and S2, Fig.S5 and S6, respectively).

During the two hours of irradiation the concentrations of ${ }^{\bullet} \mathrm{OH}$ are evaluated at different sampling times. At the same time, hydrogen peroxide concentrations are followed and no decrease of the concentration is observed (data not shown). The steady state hydroxyl radical concentrations obtained in rain and cloud waters are shown in Fig. 4. The standard deviations for steady state concentration are calculated from plots of $\mathrm{Rf}_{\mathrm{TAOH}}$ versus $\mathrm{TA}$ concentrations.

Measured hydroxyl radical concentrations for atmospheric waters range from $2.8 \times 10^{-17} \mathrm{M}$ (in rain water) to $2.0 \times 10^{-15} \mathrm{M}$ (in cloud water). Steady state hydroxyl radical concentrations in cloud waters are higher than in rain waters, with values in cloud water ranging from $2.6 \times 10^{-16}$ to $2.0 \times 10^{-15} \mathrm{M}$ with a mean value of $7.2 \pm 5.0^{\prime \prime} \times 10^{-16} \mathrm{M}$ and values in rain water ranging from $2.8 \times 10^{-17}$ to $4.3 \times 10^{-16} \mathrm{M}$ with a mean value of "1.6 $\pm 1.5^{\prime \prime} \times 10^{-16} \mathrm{M}$. Thus the value of $\left[{ }^{\bullet} \mathrm{OH}\right]_{\mathrm{ss}}$ is more than four times higher in cloud waters than in rain waters. On the contrary, no significant differences are observed between our 5 cloud samples or our 5 
rain samples. Moreover, no real correlation is found between the main parameters $\left(\mathrm{Fe}, \mathrm{H}_{2} \mathrm{O}_{2}\right.$, $\mathrm{NO}_{3}{ }^{-}$and TOC) and $\mathrm{OH}$ radical concentration. The only tendencies observed are for the rain samples with the highest TOC concentrations where the calculated $\mathrm{OH}$ radical concentrations are the lowest and for the cloud samples where the $\mathrm{OH}$ radical concentrations increase with the increase of nitrate concentration. These tendencies support the fact that TOC is a major sink for $\mathrm{OH}$ radicals in natural water (Arakaki et al., 2013) and nitrate/nitrite could be an important photochemical source of $\mathrm{OH}$ radical in such medium (Kaur and Anastasio, 2017). However, from our results, no major influence of the air mass origins of the studied clouds and rains could be detected on $\left[{ }^{\bullet} \mathrm{OH}\right]_{\mathrm{ss}}, 5$ samples are not enough and more samples should be analyzed to really conclude on this point.

After assessing the concentration of hydroxyl radicals in real atmospheric waters, the same experiments are performed with filtered waters in order to see if microorganisms can impact $\left[{ }^{\bullet} \mathrm{OH}\right]_{\mathrm{ss}}$ (Fig. 4). Concentration of hydroxyl radicals without (filtered) or with (non-filtered) microorganisms in rain waters show similar results except for two samples where concentrations are higher with the presence of microorganisms (September 17 $7^{\text {th }}, 2015$ and September $15^{\text {th }}$, 2016). This observation is even more obvious with cloud waters. Systematically, the steady state concentrations of ${ }^{\bullet} \mathrm{OH}$ are higher with microorganisms than without microflora. However the difference is not statistically significant ( $\mathrm{p}$-value $=0.81$ for rain waters and 0.06 for cloud waters, paired Wilcoxon test used), microorganism impact seems to be low, but more data are needed to strengthen this observation.

\section{Atmospheric implications and Conclusion}

A convenient method has been developed for the determination of steady state hydroxyl radical concentration in real atmospheric waters. Indeed, terephthalic acid (TA) used as a probe is non-toxic for microorganisms and therefore allows working with natural samples and 
to study the impact of the microflora. Moreover, TA is soluble in water and not volatile so the experiments can be performed in open-air conditions that are essential to work on natural samples with microorganisms. Finally another positive aspect is that because of the formation of a fluorescent product ( $\mathrm{TAOH})$ on which basis to evaluate the concentration of ${ }^{\bullet} \mathrm{OH}$, the technique is very sensitive with a limit of quantification near $10^{-17} \mathrm{M}$ and the measurement is easy to perform and fast. So, the use of TA is a very sensitive probe allowing direct assessment of the steady state concentration of hydroxyl radicals considering the sinks naturally present in the sample; it is complementary to the evaluation of the hydroxyl radical formation rates obtained in many previous studies (Faust and Allen (1993) in cloud; Nakatani et al. (2007) in rain and river, and Bianco et al. (2015) in cloud water). This result is thus important for atmospheric scientists as the steady state hydroxyl radical concentration is really a crucial parameter corresponding to the oxidant capacity of cloud water and more generally of the atmosphere.

In this study, the measured values of the steady state hydroxyl radical concentrations are within the range of few $10^{-16} \mathrm{M}$ with mean values found in cloud water of "7.2 $\pm 5.0^{\prime \prime} \times 10^{-}$ ${ }^{16} \mathrm{M}$ and in rain water of "1.6 $\pm 1.5 " \times 10^{-16} \mathrm{M}$.

As we can see in the Figure 5, our values are close to those published in different studies from cloud, rain and fog waters even though our average of steady state $\mathrm{OH}$ radical concentration in rain waters is around 10 times lower than those evaluated by Arakaki et al. (1999) and Albinet et al. (2010). This difference can be explained by the typology of the sampling sites. Indeed, Clermont-Ferrand area is much smaller than Torino or Higashi-Hiroshima and so less polluted area with less photochemical sources of $\mathrm{OH}$ radical. This is confirmed by the average concentration of nitrate in rain water measured in each site; Torino: $2.05 \mathrm{mg} \mathrm{L}^{-1}$, HigashiHiroshima $1.86 \mathrm{mg} \mathrm{L}^{-1}$ and Clermont-Ferrand $0.68 \mathrm{mg} \mathrm{L}^{-1}$. On the other hand, our $\left[{ }^{\bullet} \mathrm{OH}\right]_{\mathrm{ss}}$ 
values found in cloud waters are within the same range than those measured by Anastasio and McGregor (2001) in cloud waters and by Kaur and Anastasio (2017) in fog waters.

If we compare our mean values, the steady state hydroxyl radical concentration is four times higher in cloud water than in rain water. This higher concentration in cloud water can be also explained considering a higher concentration of photochemical sources of hydroxyl radicals in cloud than in rain waters (Lin and Peng, 1999). For example, our average concentrations of nitrate are $11.06 \mathrm{mg} \mathrm{L}^{-1}$ in cloud water and $0.68 \mathrm{mg} \mathrm{L}^{-1}$ in rain water.

Our results and comparison with the other studies show that nitrate (nitrite) could be the major precursors for photoformed ${ }^{\bullet} \mathrm{OH}$ in rain and cloud waters. This observation is in agreement with the results published in the paper of Kaur and Anastasio (2017) which found that nitrate/nitrite ions are responsible for $70 \%$ of photoformed ${ }^{\bullet} \mathrm{OH}$ in fog waters. In contrast, the study of Bianco et al. (2015) concluded that hydrogen peroxide is the most significant source of this radical (between 70 and $90 \%$ ) in cloud waters sampled at the the puy de Dôme station. This discrepancy could be due to the origin of the air masses (continental, marine, polluted), but also to the different kind of water fog or cloud and so the physicochemical properties of the collected water which can drive the photochemical reactivity. In the study of Bianco et al. (2015) no polluted samples was analysed and the puy de Dôme station in a remote site from sources of pollution.

On the contrary, our values are much lower than most of the values estimated by cloud chemistry models. Depending on the chemical scenarios (emission/deposition rates and initial chemical conditions) and on the chemical mechanisms, the estimated ${ }^{\bullet} \mathrm{OH}$ concentrations vary from $10^{-12} \mathrm{M}$ to $10^{-15} \mathrm{M}$ (Deguillaume et al., 2010; Herrmann et al., 2010; MouchelVallon et al., 2017; Tilgner and Herrmann, 2010; Tilgner et al., 2013). The highest concentration measured in the present study $\left(\sim 10^{-15} \mathrm{M}\right)$ is close to the minimal value simulated by the cloud chemistry models. This demonstrates that the models tend to 
overestimate the hydroxyl radical concentration as previously mentioned by Arakaki et al.

345 (2013). This can be explained by two reasons. First, the models are expected to underestimate

346 the radical sinks because all the organic scavengers cannot be exhaustively considered in the

347 aqueous chemical mechanism. Secondly, models are simulating the mass transfer of ${ }^{\bullet} \mathrm{OH}$ from the gas to the aqueous phase and consequently take into account an additional source not considered in the present study. This additional source is estimated to represent $69 \%$ of the total $\mathrm{OH}$ radical concentration present in aqueous phase (Kaur and Anastasio, 2017).

Moreover, thanks to this useful method, we have shown that the endogenous microflora has no significant impact on the steady state hydroxyl radical concentrations. The microorganisms could be a sink of ${ }^{\bullet} \mathrm{OH}$ radicals as any other organic matter present in clouds; however this quenching effect is suspected to be negligible as microorganisms represent a low fraction of the total organic carbon (evaluated to $1.7 \%$ by Bauer et al., 2002). On the contrary they could produce ${ }^{\bullet} \mathrm{OH}$ radicals by a passive mechanism. Indeed Samake et al. (2017) have recently reported that dead microorganisms used as bioaerosol models (bacteria and fungi) can produce ROS, although the method used does not allow to identify the type of radicals formed. Finally our results can be interpreted in two ways: i) the production or quenching of ${ }^{\bullet} \mathrm{OH}$ is too low due to the low concentration of microorganisms in clouds thus no change in $\left[{ }^{\bullet} \mathrm{OH}\right]_{\mathrm{ss}}$ can be measured; ii) the rates of production and consumption of ${ }^{\bullet} \mathrm{OH}$ by microorganisms are not negligible but within the same range of order and thus the resulting $\left[{ }^{\bullet} \mathrm{OH}\right]_{\mathrm{ss}}$ remains constant.

This convenient tool will allow the evaluation of atmospheric water oxidant capacity; it should be applied now to measure numerous samples at different sites (various altitudes, latitudes, seasons, etc.). The ${ }^{\bullet} \mathrm{OH}$ concentrations at the steady state will be used to evaluate and constrain cloud chemistry models that simulate the organic matter transformations in clouds and thus their composition, their evolution and lifetime. This will help to better assess 
369 the effect of cloud of the transformation of atmospheric organic matter that plays a crucial 370 role on air quality and climate.

371

\section{Acknowledgements}

373 This work was funded by the French ANR program BIOCAP ( ${ }^{\circ}$ ANR-13-BS06-004-01). It 374 was also supported by the French Ministry and CNRS. The authors acknowledge the financial 375 support from the Observatoire de Physique du Globe de Clermont-Ferrand (OPGC) and from 376 the Fédération des Recherches en Environnement through the CPER founded by Région 377 Auvergne Rhône-Alpes, the French ministry, and FEDER from the European community 


\section{REFERENCES}

Albinet, A., Minero, C., and Vione, D., 2010. Photochemical generation of reactive species upon irradiation of rainwater: Negligible photoactivity of dissolved organic matter. Sci. Total Environ. 408, 3367-3373.

Amato, P., Parazols, M., Sancelme, M., Laj, P., Mailhot, G., and Delort, A.-M., 2007a. Microorganisms isolated from the water phase of tropospheric clouds at the puy de Dôme: major groups and growth abilities at low temperatures. FEMS Microbiol. Ecol. 59, 242-254.

Amato, P., Demeer, F., Melaouhi, A., Fontanella, S., Martin-Biesse, A.-S., Sancelme, M., Laj, P., and Delort, A.-M., 2007b. A fate for organic acids, formaldehyde and methanol in cloud water: Their biotransformation by micro-organisms. Atmos. Chem. Phys. 7, 4159-4169.

Anastasio, C., and McGregor, K.G.,2001. Chemistry of fog waters in California's Central Valley: 1. In situ photoformation of hydroxyl radical and singlet molecular oxygen. Atmos. Environ. 35, 1079-1089.

Arakaki, T., and Faust, B.C., 1998. Sources, sinks, and mechanisms of hydroxyl radical $\left({ }^{\bullet} \mathrm{OH}\right)$ photoproduction and consumption in authentic acidic continental cloud waters from Whiteface Mountain, New York: The role of the Fe(r) ( $\mathrm{r}=\mathrm{II}$, III) photochemical cycle. J. Geophys. Res. 103, 3487-3504.

Arakaki, T., Miyake, T., Shibata, M., and Sakugawa, H., 1999. Photochemical formation and scavenging of hydroxyl radical in rain and dew waters. Nippon Kag. Kaish. 5, 335-340.

Arakaki, T., Anastasio, C., Kuroki, Y., Nakajima, H., Okada, K., Kotani, Y., Handa, D., Azechi, S., Kimura, T., Tsuhako, A., et al., 2013. A general scavenging rate constant for reaction of hydroxyl radical with organic carbon in atmospheric waters. Environ. Sci. Technol. 47, 8196-8203.

Ariya, P.A., Nepotchatykh, O., Ignatova, O., and Amyot, M., 2002. Microbiological degradation of atmospheric organic compounds. Geophys. Res. Lett. 29, 34-1-34-4. 
Bauer, H., Kasper-Giebl, A., Löflund, M., Giebl, H., Hitzenberger, R., Zibuschka, F., and Puxbaum, H., 2002. The contribution of bacteria and fungal spores to the organic carbon content of cloud water, precipitation and aerosols. Atmos. Res. 64, 109-119.

Bianco, A., Passananti, M., Perroux, H., Voyard, G., Mouchel-Vallon, C., Chaumerliac, N., Mailhot, G., Deguillaume, L., and Brigante, M., 2015. A better understanding of hydroxyl radical photochemical sources in cloud waters collected at the puy de Dôme station experimental versus modelled formation rates. Atmos. Chem. Phys. 15, 9191-9202.

Bianco, A., Voyard, G., Deguillaume, L., Mailhot, G., and Brigante, M., 2016. Improving the characterization of dissolved organic carbon in cloud water: Amino acids and their impact on the oxidant capacity. Sci. Rep. 6.

Blough, N.V., and Zepp, R.G., 1995. Reactive oxygen species in natural waters. In Active Oxygen in Chemistry, C. S. Foote, J. Valentine, A. Greenberg and J. F. Liebman (Springer), pp. 280-330.

Brezonik, P.L., and Fulkerson-Brekken, J., 1998. Nitrate-induced photolysis in natural waters: Controls on concentrations of hydroxyl radical photo-intermediates by natural scavenging agents. Environ. Sci. Technol. 32, 3004-3010.

Buxton, G.V., Greenstock, C.L., Helman, W.P. and Ross, A.B., 1988. Critical review of rate constants for reactions of hydrated electrons, hydrogen atoms and hydroxyl radicals $\left({ }^{\circ} \mathrm{OH} /{ }^{\circ} \mathrm{O}^{-}\right)$ in aqueous solution. J. Phys. Chem. Ref. Data 17, 513-886.

Chameides, W.K., and Davis, D.D., 1982. The free radical chemistry of cloud droplets and its impact upon the composition of rain. J. Geophys. Res. 87, 4863-4877.

Charbouillot, T., Brigante, M., Mailhot, G., Maddigapu, P.R., Minero, C., and Vione, D., 2011. Performance and selectivity of the terephthalic acid probe for $\mathrm{OH}$ as a function of temperature, $\mathrm{pH}$ and composition of atmospherically relevant aqueous media. J. Photochem. Photobiol. A 222, 70-76. 
Deguillaume, L., Leriche, M., Monod, A., and Chaumerliac, N., 2004. The role of transition metal ions on HOx radicals in clouds: A numerical evaluation of its impact on multiphase chemistry. Atmos. Chem. Phys. 4, 95-110.

Deguillaume, L., Leriche, M., and Chaumerliac, N., 2005. Impact of radical versus nonradical pathway in the Fenton chemistry on the iron redox cycle in clouds. Chemosphere 60, $718-724$.

Deguillaume, L., Desboeufs, K.V., Leriche, M., Long, Y., and Chaumerliac, N., 2010. Effect of iron dissolution on cloud chemistry: From laboratory measurements to model results. Atmos. Poll. Res. 1, 220-228.

Deguillaume, L., Charbouillot, T., Joly, M., Vaïtilingom, M., Parazols, M., Marinoni, A., Amato, P., Delort, A.-M., Vinatier, V., Flossmann, A., et al., 2014. Classification of clouds sampled at the puy de Dôme (France) based on $10 \mathrm{yr}$ of monitoring of their physicochemical properties. Atmos. Chem. Phys. 14, 1485-1506.

Faust, B.C., 1994. Photochemistry of clouds, fogs, and aerosols. Environ. Sci. Technol. 28, 217A-222A.

Faust, B.C., and Allen, J.M., 1993. Aqueous-phase photochemical formation of hydroxyl radical in authentic cloudwaters and fog waters. Environ. Sci. Technol. 27, 1221-1224.

Faust, B.C., and Hoigné, J., 1990. Photolysis of Fe (III)-hydroxy complexes as sources of OH radicals in clouds, fog and rain. Atmos. Environ. 24, 79-89.

Faust, B.C., and Zepp, R.G., 1993. Photochemistry of aqueous iron (III)-polycarboxylate complexes: Roles in the chemistry of atmospheric and surface waters. Environ. Sci. Technol. $27,2517-2522$.

Haag, W.R., and Hoigné, J., 1985. Photo-sensitized oxidation in natural water via OH radicals. Chemosphere 14, 1659-1671. 
Herckes, P., Valsaraj, K.T., and Collett, J.L., 2013. A review of observations of organic matter in fogs and clouds: Origin, processing and fate. Atmos. Res. 132, 434-449.

Herrmann, H., Ervens, B., Jacobi, H.-W., Wolke, R., Nowacki, P., and Zellner, R., 2000.

CAPRAM2.3: A chemical aqueous phase radical mechanism for tropospheric chemistry. Journal of Atmospheric Chemistry 36, 231-284.

Herrmann, H., Hoffmann, D., Schaefer, T., Bräuer, P., and Tilgner, A., 2010. Tropospheric aqueous-phase free-radical chemistry: Radical sources, spectra, reaction kinetics and prediction tools. ChemPhysChem 11, 3796-3822.

Herrmann, H., Schaefer, T., Tilgner, A., Styler, S. A., Weller, C., Teich, M., Otto, T., 2015. Tropospheric aqueous-phase chemistry: kinetics, mechanisms, and its coupling to a changing gas phase. Chem. Rev. 115 (10), 4259-4334.

al Housari, F., Vione, D., Chiron, S., and Barbati, S., 2010. Reactive photo-induced species in estuarine waters. Characterization of hydroxyl radical, singlet oxygen and dissolved organic matter triplet state in natural oxidation processes. Photochem. Photobiol. Sci. 9, 78-86.

Husarova, S., Vaïtilingom, M., Deguillaume, L., Traïkia, M., Vinatier, V., Sancelme, M., Amato, P., Matulova, M., Delort, A.-M, 2011. Biotransformation of methanol and formaldehyde by bacteria isolated from clouds. Comparison with radical chemistry. Atmos. Environ. 45, 6093-6102.

Jacob, D.J., 1986. Chemistry of $\mathrm{OH}$ in remote clouds and its role in the production of formic acid and peroxymonosulfate. J. Geophys. Res. 91, 9807-9826.

Joly, M., Amato, P., Sancelme, M., Vinatier, V., Abrantes, M., Deguillaume, L., and Delort, A.-M., 2015. Survival of microbial isolates from clouds toward simulated atmospheric stress factors. Atmos. Environ. 117, 92-98.

Kaur, R. and Anastasio, C., 2017. Light absorption and the photoformation of hydroxyl radical and singlet oxygen in fog waters. Atmos. Environ., 164, 387-397. 
Lelieveld, J., and Crutzen, P.J., 1991. The role of clouds in tropospheric photochemistry. J. Atmos. Chem. 12, 229-267.

Lelieveld, J., Dentener, F.J., Peters, W., and Krol, M.C., 2004. On the role of hydroxyl radicals in the self-cleansing capacity of the troposphere. Atmos. Chem. Phys. 4, 2337-2344. Lin, N.-H., and Peng, C.-M., 1999. Estimates of the contribution of below-cloud scavenging to the pollutant loadings of rain in Taipei, Taiwan. Terrestrial, Atmos. Ocean. Sci. 10, 693704.

Mauldin III, R.L., Madronich, S., Flocke, S.J., and Eisele, F.L., 1997. New insights on OH: measurements around and in clouds. Geophys. Res. Lett. 24, 3033-3036.

Metallo, C. M.; Vander Heiden, M. G., 2013. Understanding Metabolic Regulation and Its Influence on Cell Physiology. Mol. Cell. 49 (3), 388-398.

Mill, T., Hendry, D.G., and Richardson, H., 1980. Free-radical oxidants in natural waters. Science 207, 886-887.

Mouchel-Vallon, C., Deguillaume, L., Monod, A., Perroux, H., Rose, C., Ghigo, G., Long, Y., Leriche, M., Aumont, B., and Patryl, L., 2017. CLEPS 1.0: A new protocol for cloud aqueous phase oxidation of VOC mechanisms. Geosci. Model Dev. 10, 1339-1362.

Nakatani, N., Ueda, M., Shindo, H., Takeda, K., and Sakugawa, H., 2007. Contribution of the photo-Fenton reaction to hydroxyl radical formation rates in river and rain water samples. Anal. Sci. 23, 1137-1142.

Page S.E., Arnold, W.A., McNeill K., 2010. Terephthalate as a probe for photchemically generated hydroxyl radical. J. Environ. Monit. , 12, 1658-1665.

Parazols, M., Marinoni, A., Amato, P., Abida, O., Laj, P., Mailhot, G., Delort, A.-M., and Sergio, Z., 2007. Speciation and role of iron in cloud droplets at the puy de Dôme station. J. Atmos. Chem. 57, 299-300. 
Qian, J., Mopper, K., and Kieber, D.J., 2001. Photochemical production of the hydroxyl radical in Antarctic waters. Deep Sea Res. Part I Oceanogr. Res. Pap. 48, 741-759.

Russi, H., Kotzias, D., and Korte, F., 1982. Photoinduzierte hydroxylierungsreaktionen organischer chemikalien in natürlichen Gewässern-Nitrate als potentielle $\mathrm{OH}$-radikalquellen. Chemosphere 11, 1041-1048.

Samake, A., Uzu, G., Martins, J.M.F., Calas, A., Vince, E., Parat, S., and Jaffrezo, J.L., 2017. The unexpected role of bioaerosols in the oxidative potential of PM. Sci. Rep. 7.

Shingler, V., 2003. Integrated Regulation in Response to Aromatic Compounds: From Signal Sensing to Attractive Behaviour. Environ. Microbiol. 5 (12), 1226-1241.

Tilgner, A., and Herrmann, H., 2010. Radical-driven carbonyl-to-acid conversion and acid degradation in tropospheric aqueous systems studied by CAPRAM. Atmos. Environ. 44, $5415-5422$.

Tilgner, A., Bräuer, P., Wolke, R., and Herrmann, H., 2013. Modelling multiphase chemistry in deliquescent aerosols and clouds using CAPRAM3.0i. J. Atmos. Chem. 70, 221-256.

Tropel, D., van der Meer, J. R., 2004. Bacterial Transcriptional Regulators for Degradation Pathways of Aromatic Compounds. Microbiol. Mol. Biol. Rev. 68 (3), 474-500.

Vaïtilingom, M., Amato, P., Sancelme, M., Laj, P., Leriche, M., and Delort, A.-M., 2010. Contribution of microbial activity to carbon chemistry in clouds. Appl. Environ. Microbiol. $76,23-29$.

Vaïtilingom, M., Charbouillot, T., Deguillaume, L., Maisonobe, R., Parazols, M., Amato, P., Sancelme, M., and Delort, A.-M., 2011. Atmospheric chemistry of carboxylic acids: Microbial implication versus photochemistry. Atmos. Chem. Phys. 11, 8721-8733.

Vaïtilingom, M., Attard, E., Gaiani, N., Sancelme, M., Deguillaume, L., Flossmann, A.I., Amato, P., and Delort, A.-M., 2012. Long-term features of cloud microbiology at the puy de Dôme (France). Atmos. Environ. 56, 88-100. 
Vaïtilingom, M., Deguillaume, L., Vinatier, V., Sancelme, M., Amato, P., Chaumerliac, N., and Delort, A.-M., 2013. Potential impact of microbial activity on the oxidant capacity and organic carbon budget in clouds. Proc. Natl. Acad. Sci. 110, 559-564.

Weschler, C.J., Mandich, M.L., and Graedel, T.E., 1986. Speciation, photosensitivity and reactions of transition metal ions in atmospheric droplets. J. Geophys. Res. 91, 5189-5204.

Wirgot, N., Vinatier, V., Deguillaume, L., Sancelme, M., Delort, A.-M., 2017. $\mathrm{H}_{2} \mathrm{O}_{2}$ modulates the energetic metabolism of the cloud microbiome. Atmos. Chem. Phys. 17, 14841-14851.

Yu, X.-Y., and Barker, J.R., 2003. Hydrogen peroxide photolysis in acidic aqueous solutions containing chloride ions. I. Chemical mechanism. J. Phys. Chem. A 107, 1313-1324.

Zafiriou, O.C., and Bonneau, R., 1987. Wavelength-dependent quantum yield of OH radical formation from photolysis of nitrite ion in water. Photochem. Photobiol. 45, 723-727.

Zellner, R., Exner, M., and Herrmann, H., 1990. Absolute OH quantum yields in the laser photolysis of nitrate, nitrite and dissolved $\mathrm{H}_{2} \mathrm{O}_{2}$ at 308 and $351 \mathrm{~nm}$ in the temperature. Atmos. Chem. 10, 411-425.

Zepp, R.G., Hoigne, J., and Bader, H., 1987. Nitrate-induced photooxidation of trace organic chemicals in water. Environ. Sci. Technol. 21, 443-450.

Zhou, X., and Mopper, K., 1990. Determination of photochemically produced hydroxyl radicals in seawater and freshwater. Mar. Chem. 30, 71-88. 


\section{Figure captions:}

547 Fig. 1: Comparison of actinic fluxes of the lamp used in the present work together with the ones measured under natural conditions during cloudy and sunny situations at the puy de Dôme station

549 (Solar emission in cloudy condition was measured in October $16^{\text {th }}, 2013$ and in sunny condition in

550

551

552

553

554

555

556

557

558

559

560

561

562

563

564

565

Fig. 2: Reaction between TA and ${ }^{\bullet} \mathrm{OH}$.

Fig. 3: Evolutions of the number of cells (A) and of the concentration of ATP (B) as a function of time $(0,47$ and $72 \mathrm{~min})$ in the presence of 3 probe concentrations $(0,4$ and $10 \mu \mathrm{M})$.

Fig. 4: Concentrations of hydroxyl radicals at steady state in rain and cloud waters without (white histogram) and with microorganisms (dash histogram). Error bars represent standard variation from plots of $\mathrm{Rf}_{\mathrm{TAOH}}$ versus TA concentrations.

Fig 5: Measured of steady state hydroxyl radical concentrations by different research groups in different atmospheric waters (cloud, fog and rain). 


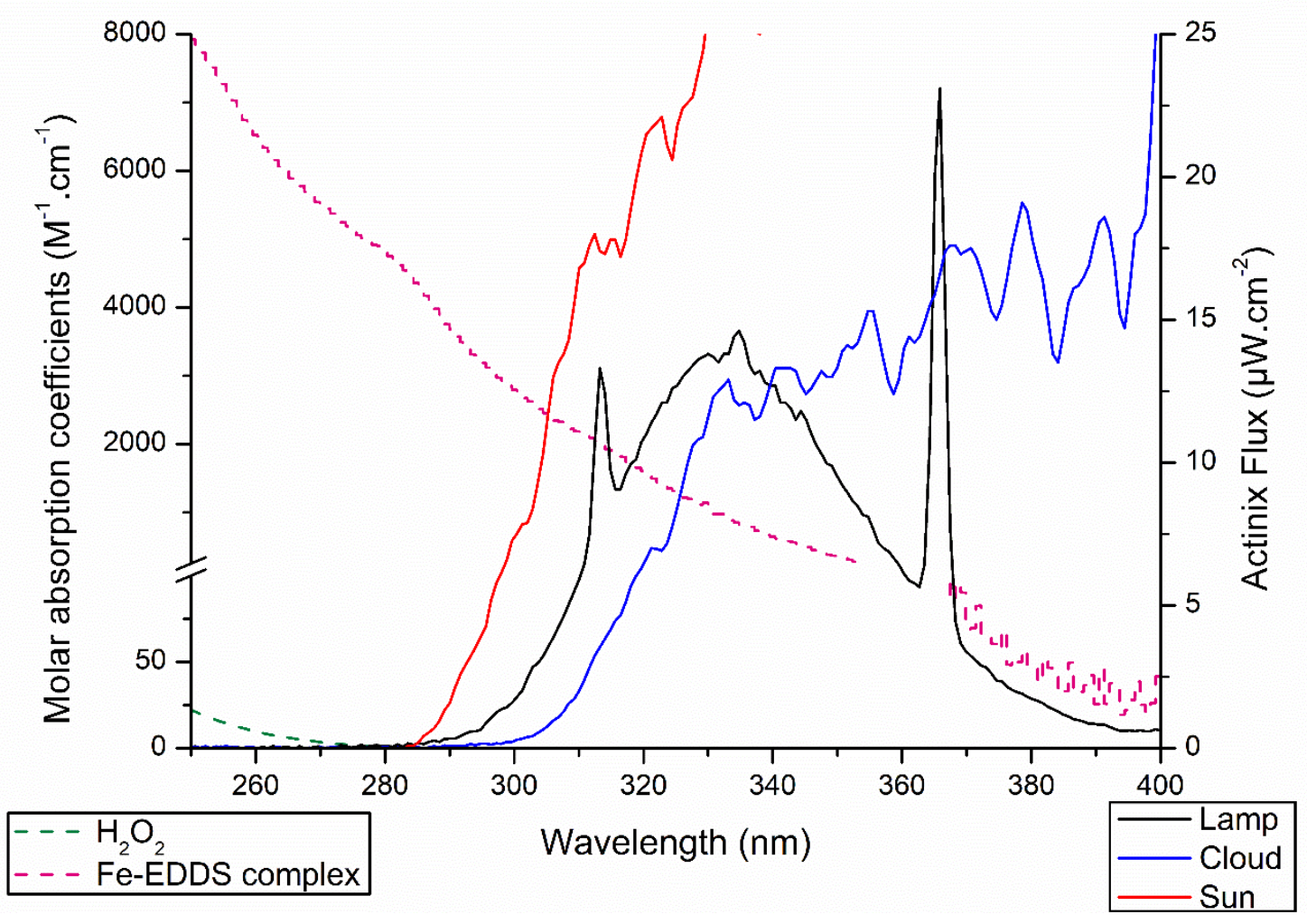

$568 \quad$ Fig. 1

569

570<smiles>O=C(O)c1ccc(C(=O)O)cc1</smiles>

Terephthalic acid

2-hydroxyterephthalic acid (TAOH)

572

$573 \quad$ Fig. 2 

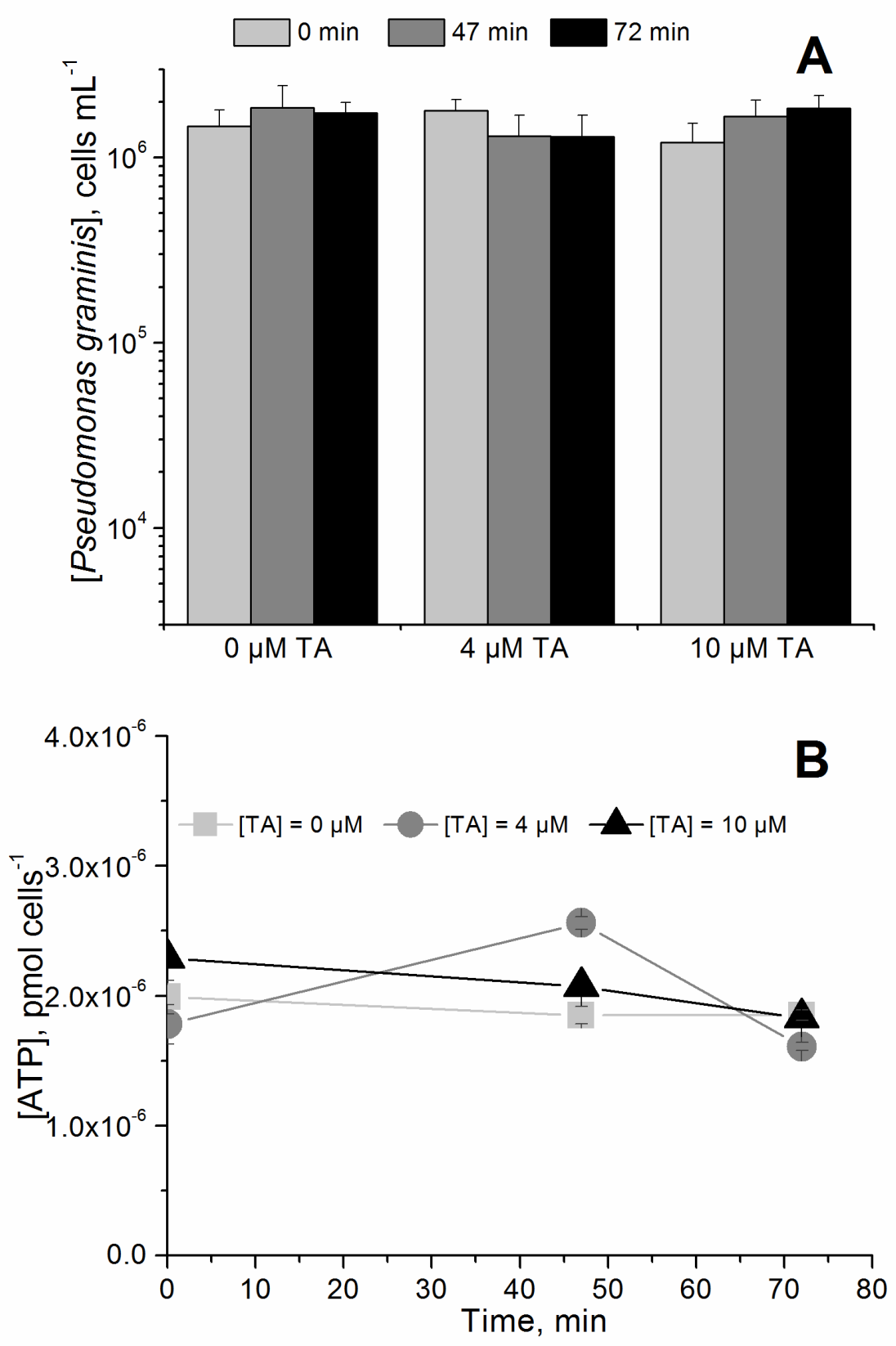

$578 \quad$ Fig. 3

579

580

581 

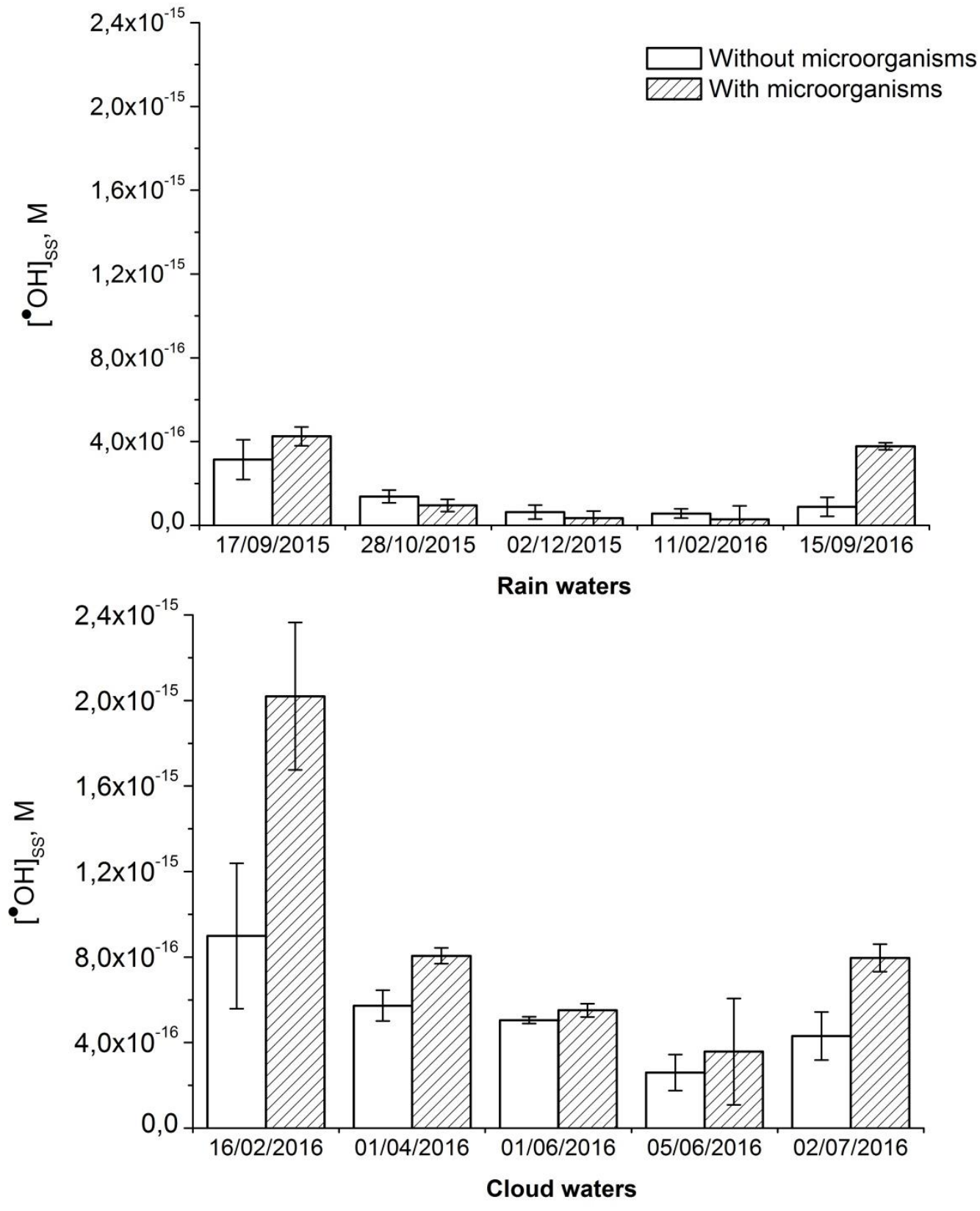

582

$583 \quad$ Fig. 4

584

585

586

587

588

589

590 


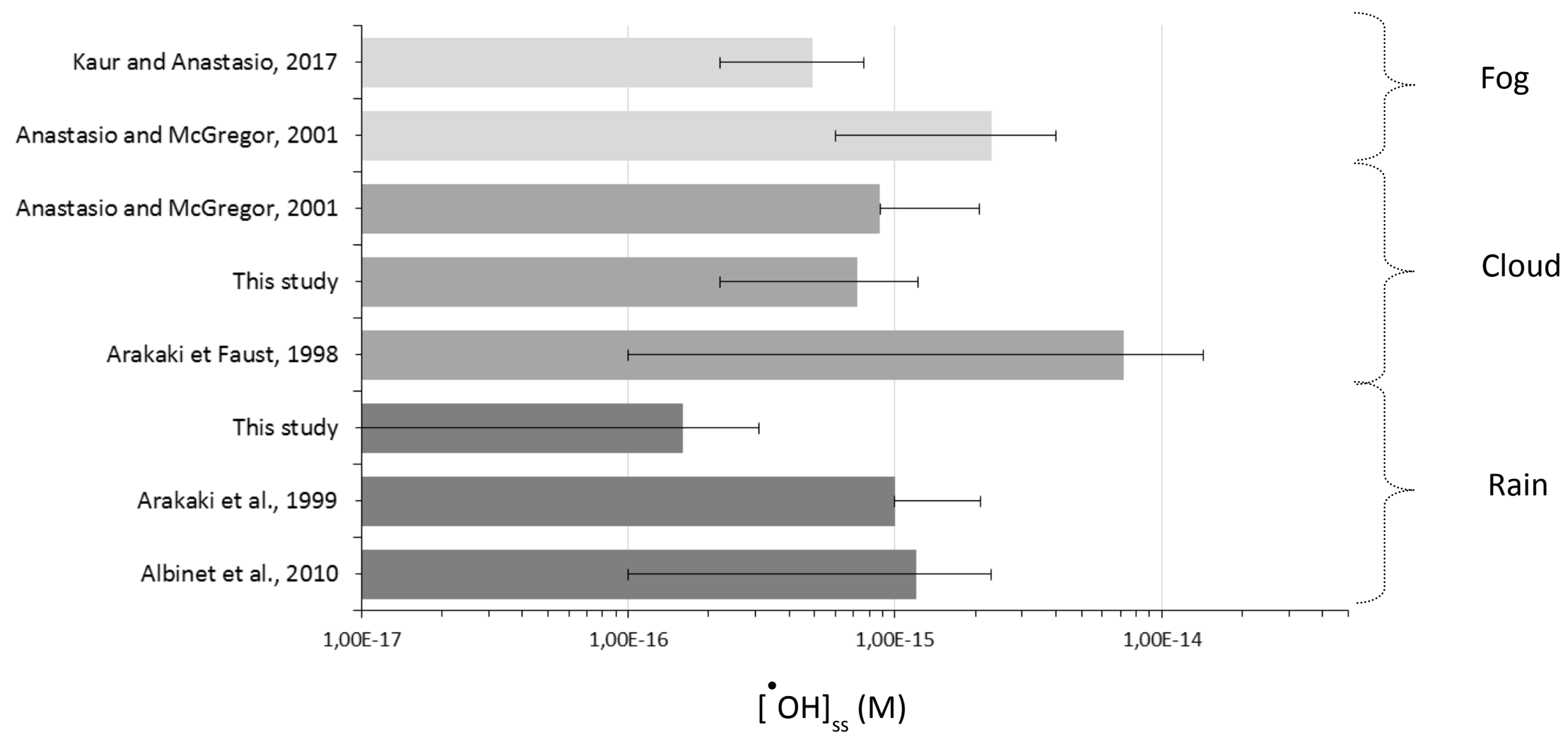

604

Fig 5 